\title{
Analysis of Coconut Supply Chain as Industry Potential in Sula Islands Regency, North Maluku Province
}

\author{
Akhmad Sutoni \\ Teknik Industri Universitas Suryakancana \\ Jl. Pasir Gede Raya, Cianjur, Indonesia \\ tbungsu13@gmail.com
}

Dikirimkan: 03, 2020. Diterima: 03, 2020. Dipublikasikan: 03, 2020.

\begin{abstract}
The supply chain management of the coconut industry in the Sula Islands district is still felt to be ineffective and inefficient. The advantage of effective supply chain management is to get maximum speed when goods and services move through the supply chain channel, lower costs, and increase added value for customers and product competitiveness in the market. The purpose of this study is to identify and analyze the management of the coconut industry supply chain. The method used is descriptive qualitative analysis. Those who play a role in the coconut supply chain in the Sula Islands district are farmers, collectors I, collectors II, owners of home industries, transport vehicle owners and marine vessels as modes of transportation. With this supply chain channel, there are only a few benefits for farmers and business operators. The added value of coconut and copra is very small, meaning that the economic value obtained is very small. To provide greater economic value for residents of the Sula Islands district, especially for coconut farmers and coconut entrepreneurs, so coconut fruit must be processed not only until copra, but made in industrial scale coconut oil.
\end{abstract}

Keywords-Supply Chain; Coconut; Industry; Coconut oil; Sula Islands Regency.

\begin{abstract}
Abstrak - Manajemen rantai pasok industri kelapa di kabupaten Kepulauan Sula masih dirasakan belum efektif dan efisien. Keuntungan manajemen rantai pasok yang efektif adalah untuk mendapatkan kecepatan maksimal pada saat barang dan jasa bergerak melalui jalur rantai pasok, menurunkan biaya, serta meningkatkan nilai tambah bagi pelanggan dan daya saing produk di pasar. Tujuan dari penelitian ini adalah mengidentifikasi dan menganalisis pengelolaan rantai pasokan industri kelapa. Metode yang digunakan adalah Analisis deskriptif kualitatif. Yang berperan dalam rantai pasokan kelapa di kabupaten Kepulauan Sula adalah petani, pengepul I, pengepul II, pemilik industri rumahan, pemilik kendaraan angkut dan kapal laut sebagai moda transportasi. Dengan jalur Rantai Pasokan seperti ini hanya sedikit keuntungan yang didapat oleh petani maupun pelaku usaha. Nilai Tambah dari Kelapa dan Kopra sangat kecil, berarti Nilai ekonomi yang didapatpun sangat kecil. Untuk memberikan nilai ekonomi lebih besar bagi penduduk kabupaten Kepulauan Sula, terutama bagi petani Kelapa dan pelaku usaha Kelapa, makanya buah Kelapa harus diolah tidak hanya sampai Kopra, tetapi dibuat minyak Kelapa berskala industri.
\end{abstract}

Kata kunci-Rantai Pasok; Kelapa; Industri; Minyak Kelapa; Kabupaten Kepulauan Sula.

\section{Pendahuluan}

\section{A. Latar Belakang}

Kebijakan pengembangan industri nasional telah diamatkan pada Peraturan Presiden No. 28 Tahun 2008. Dalam Pasal 3 tercantum bahwa "Pemerintah Provinsi menyusun peta panduan pengembangan industri unggulan provinsi dan pemerintah Kabupaten/ Kota menyusun peta panduan pengembangan kompetensi inti industri kabupaten/ kota, serta Menteri yang bertugas dan bertanggung jawab di bidang perindustrian menetapkan peta panduan pengembangan industri unggulan Provinsi dan peta panduan kompetensi inti industri Kabupaten/Kota. Sesuai amanat [1]
Rencana Induk Pengembangan Industri Nasional (RIPIN) dan Kebijakan Industri Nasional (KIN), dalam rangka membangun daya saing industri secara berkelanjutan telah ditetapkan strategi operasional dengan pendekatan Perencanaan

Pembangunan Industri dilakukan dari 2 (dua) arah yaitu : pertama, pendekatan top-down yaitu pembangunan industri yang direncanakan (bydesign) dengan memperhatikan kriteria yang ditentukan secara nasional yaitu 32 industri prioritas dengan pendekatan klaster. Kedua, melalui pendekatan perencanaan secara bottom-up yaitu melalui penetapan kompetensi inti yang berlandaskan pada potensi yang dimiliki daerah 


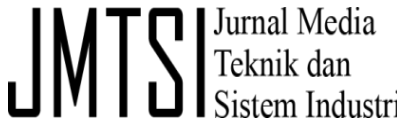

dan merupakan keunggulan daerah sehingga daerah memiliki daya saing.

Sektor Industri memegang peran kunci sebagai mesin pembangunan karena sektor Industri memiliki beberapa keunggulan dibandingkan sektor lain yang ditunjukkan dengan nilai kapitalisasi modal yang tertanam sangat besar, kemampuan menyerap tenaga kerja yang besar, juga kemampuan menciptakan nilai tambah (value added creation) dari setiap input atau bahan dasar yang diolah.

Selain itu, yang melatarbelakangi penelitian ini adalah karena manajemen rantai pasok industri kelapa masih dirasakan belum efektif dan efisien. Keuntungan manajemen rantai pasok yang efektif adalah untuk mendapatkan kecepatan maksimal pada saat barang dan jasa bergerak melalui jalur rantai pasok, menurunkan biaya, serta meningkatkan nilai tambah bagi pelanggan dan daya saing produk di pasar.

Menurut [2], salah satu faktor kunci untuk mengoptimalkan rantai pasok adalah dengan menciptakan alur informasi yang bergerak secara mudah dan akurat di antara jaringan atau mata rantai tersebut, dan pergerakan barang yang efektif dan efisien yang menghasilkan kepuasan maksimal pada para konsumen. Selain keterkaitannya dengan jaminan pasar, unsur pendukung di hulu seperti penyediaan bahan baku, sarana produksi dan unsur penunjang lainnya. Satu dari unsur penting keberlanjutan usaha adalah terbangunnya manajemen rantai pasok dari industri tersebut. Manajemen rantai pasok yang dimaksud adalah modifikasi praktek tradisional dari manajemen logistik, yang mementingkan pihak- pihak secara individual dan ukan mengacu kepada kinerja keseluruhan ke arah koordinasi dan kemitraan antara pihak-pihak yang terlibat [3]. [4] menyatakan bahwa manajemen rantai pasokan merupakan salah satu strategi yang sangat penting dalam menyelesaikan permasalahan perusahaan, mengenai keputusan aktivitas penyedia bahan baku, produsen (perusahaan) dan konsumen. Sehingga suatu sistem produksi yang efektif dan efisien merupakan keharusan yang dimiliki oleh para pelaku bisnis agar dapat memenangkan persaingan.

Faktor lain yang melatarbelakangi penelitian ini adalah karena tingginya permintaan minyak kelapa di pasar dunia. Pada tahun 2014, kebutuhan minyak kelapa dunia sebesar 2,18 juta ton per tahun dengan nilai pasar sebesar 3,11 milyar US dolar [5]. Pangsa pasar minyak kelapa dunia dipasok oleh dua negara produsen yaitu Indonesia dan Philipina dengan total pangsa pasar sebesar $76,86 \%$. Pangsa pasar masing-masing negara produsen tersebut terhadap dunia pada tahun 2014 sebesar 35,31\% untuk Indonesia dan 41,55\% untuk Philipina, sisanya sebesar $8,58 \% ; 8,59 \% ; 1,44 \%$ secara berturut-turut dipasok oleh Netherland (Belanda), Malaysia dan Amerika Serikat serta sisanya sebesar 4,53\% dipasok oleh negara-negara lainnya. Indonesia dan Philippina menjadi produsen minyak kelapa terbesar karena wilayahnya yang berada di wilayah tropis dan merupakan negara kepulauan terbesar di dunia yang mendukung untuk tumbuh dan berkembangnya tanaman kelapa. Oleh karena itu, produksi minyak kelapa (CCO) dari kedua negara ini dapat mendominasi pangsa pasar dunia (Gambar 1).

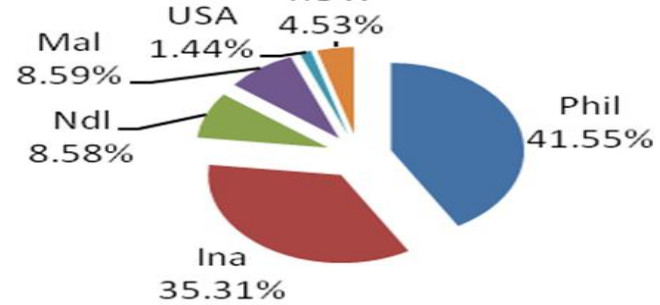

Gambar 1. Porsi ekspor minyak kelapa negara eksportir di pasar dunia tahun 2014 [5]

Letak geografis Indonesia sebagai negara tropis menjadikan suatu keunggulan bagi pengembangan komoditas CCO, karena bahan baku kelapa yang melimpah. Potensi perluasan lahan perkebunan kelapa sebesar 10,70 juta hektar masih bisa dilakukan yang letaknya di Papua, Kalimantan, dan Riau [6]. Akan tetapi kekuatan tawar petani masih lemah. Produktivitas petani kecil yang rendah dan kesenjangan besar dalam keuntungan per hektar, kurangnya akses ke layanan keuangan dan teknis, dan kurangnya perwakilan yang memadai dalam perencanaan dan pengambilan keputusan di tingkat perusahaan perkebunan dan industri minyak. Bahwa petani menerima harga yang rendah padahal menghadapi risiko lebih tinggi dibandingkan dengan pabrik $\mathrm{CCO}$ yang mempertahankan tingkat margin usahanya. Muncul kebutuhan untuk mengetahui apa saja jenis-jenis risiko dan bobot dampaknya kepada tiap pelaku rantai pasok dari kenyataankenyataan tersebut.

\section{B. Perumusan Masalah}

Berdasarkan latar belakang di atas, maka rumusan masalah dari penelitian ini adalah bagaimana mengelola rantai pasok agar performansi industri kelapa lebih baik.

Atas dasar itulah maka pertanyaan penelitian ini (Research Question) adalah:

1) Bagaimana melakukan identifikasi model rantai pasok industri kelapa? 
2) Bagaimana cara mengelola rantai pasokan industri kelapa?

\section{Tujuan Penelitian}

Tujuan dari penelitian ini adalah :

1) Mengidentifikasi model rantai pasok industri kelapa.

2) 2. Menganalisis pengelolaan rantai pasokan industri kelapa.

\section{Tinjauan Pustaka}

Kelapa (Cocos nucifera L.) sebagai salah satu kekayaan hayati Indonesia telah berabad-abad dimanfaatkan oleh masyarakat untuk memenuhi berbagai kebutuhan, baik sebagai sumber makanan, obat-obatan, industri dan lain-lain. Hasil-hasil produk kelapa di Indonesia secara umum masih bertumpu pada minyak kelapa, padahal kelapa merupakan tanaman yang serbaguna. Tanaman kelapa memiliki keragaman produk yang tinggi, karena dari daun sampai akar memiliki manfaat dan nilai sosial ekonomi.

Rantai pasokan adalah sebuah proses bisnis dan informasi yang berulang yang menyediakan produk atau layanan dari pemasok melalui proses pembuatan dan pendistribusian kepada konsumen [7]. Manajemen rantai pasokan adalah perencanaan desain dan kontrol aliran informasi dan material di sepanjang rantai pasokan dalam rangka memenuhi kebutuhan pelanggan secara efisien sekarang dan di masa depan [7]. [8] juga mengatakan manajemen rantai pasokan adalah pengelolaan kegiatan, bahan,pengadaan,dan jasa mentransformasikannya menjadi barang setengah jadi dan produk akhir dan memberikan produk malalui distribusi. Dari definisi diatas dapat disimpulkan bahwa rantai pasokan adalah sekumpulan aktivitas yang berkaitan dengan pemasok, manufaktur, gudang, jasa transportasi, pengecer, dan konsumen atau hubungan dari hulu (upstreams) ke hilir (downstreams) secara efisien dan efektif sehingga barang dan jasa dapat didistribusikan dalam jumlah, waktu dan lokasi yang tepat. [9] mendefinisikan saluran distribusi sebagai struktur unit-unit organisasi antar perusahaan dengan agen-agen dan dealer-dealer ekstra perusahaan, grosir dan eceran, melalui nama komoditi, produk atau jasa-jasa dipasarkan, atau sebagai pengelompokkan para perantara yang mempunyai hak terhadap suatu produk selama proses pemasaran, mulai dari pemilik pertama sampai kepada pemilik terakhir [10] dan [11].

Metode yang digunakan adalah analisis data kualitatif. Tujuan penelitian ini adalah ingin mengetahui pihak-pihak yang terlibat dalam rantai pasokan, bagaimana proses saluran distribusi, dan bagaimana rantai pasokan kopra dan produk turunan kelapa [12], berjudul analisis pengelolaan rantai pasok tepung kelapa pada P.T. XYZ di Sulawesi Utara. Metode yang digunakan adalah analisis kualitatif deskriptif. Tujuannya adalah mengidentifikasi model dan menganalisis pengelolaan rantai pasokan tepung kelapa pada P.T. XYZ. [13], berjudul Pengelolaan Rantai Pasok dan Daya saing Kelapa Sawit di Aceh Utara. Metode yang digunakan adalah analisis kuantitatif dan kualitatif yang diawali dengan penyususnan matriks semua indikator, yaitu luas panen, produksi, harga jual petani, harga jual Satuan Pengumpul, dan pendapatan petani kelapa sawit. Tujuan penelitiannya adalah menganalisis nilai tambah dalam system rantai pasok, dan menganalisis faktor-faktor yang berpengaruh terhadap inerja peningkatan keunggulan kompetitif bagi perkebunan kelapa sawit [14], berjudul Model identifikasi Risiko dan strategi peningkatan nilai tambah pada rantai pasok kelapa sawit. Metode yang digunakan adalah FuzzyAHP. Tujuan penelitiannya adalah menghasilkan model untuk mengidentifikasi faktor-faktor risiko, mengukur tingkat kepentingan risiko, mendapatkan alternatif strategi untuk peningkatan nilai tambah, dan menentukan urutan prioritasnya [15], dengan judul analisis kelembagaan rantai pasok agroindustry kopra (studi kasus di kabupaten Halmahera Timur). Metode yang digunakan adalah Interpretive Structural Model (ISM). Tujuan penelitiannya adalah untuk membuat strategi pengembangan agroindustri melalui pengembangan kelembagaan rantai pasok yang mengkoordinir agroindustri kopra di Halmahera Timur.

Penelitian ini merupakan penelitian lanjutan dari [16] berjudul Determination Of Regional Main Products With Fuzzy Logic Approach In Regional Sula Island Of North Maluku Province (Penentuan Produk Unggulan Daerah Dengan Pendekatan Logika Fuzzy Di Kabupaten Kepulauan Sula, Provinsi Maluku Utara). Dari beberapa Produk Unggulan Prioritas yang ada di kabupaten Kepulauan Sula, kemudian dianalisis berdasarkan Produktivitas, berdasarkan Produk Domestik Regional Bruto (PDRB) dan analisis hasil perhitungan Location Quotient (LQ). Hasil analisis tersebut penentuan produk unggulannya menggunakan metode Fuzzy, dan didapat Produk Kelapa sebagai Produk Unggulan Daerah. 


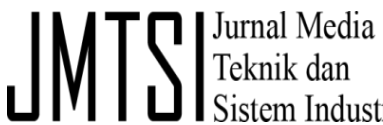

TABEL I

SEKTOR UNGGULAN PRODUKSI TANAMAN PERKEBUNAN

\begin{tabular}{|c|c|r|}
\hline No & Tanaman Perkebunan & Produksi \\
\hline 1 & Kelapa & 31,676 \\
\hline 2 & Kakao & 3,564 \\
\hline 3 & Cengkeh & 1,148 \\
\hline 4 & Kacang Mede & 1,148 \\
\hline
\end{tabular}

Sumber : [16]

TABEL II

Perhitungan LQ Produksi PERKEBUnan DI KABUPATEN KEPULAUAN SULA, 2015

\begin{tabular}{|c|c|}
\hline Plantation & LQ \\
\hline Coconut & 0.94 \\
\hline Rubber & 0 \\
\hline Cocoa & 1.92 \\
\hline Coffee & 3.04 \\
\hline Clowe & 1.81 \\
\hline Pala & 0.27 \\
\hline Castiew & 3.09 \\
\hline Pepper & 0 \\
\hline Vanilla & 0 \\
\hline Caput & 0 \\
\hline Palm Suga & 0 \\
\hline Cinnamon & 0 \\
\hline \hline
\end{tabular}

Sumber : [16]

Dari hasil perhitungan untuk Produk Domestik Regional Bruto baik dengan Harga Konstan, atau Harga Saat Ini diperoleh Nilai LQ > 1 adalah Bidang Usaha[16] :

1) Pertanian, Perkebunan dan Perikanan

2) Industri Pengolahan

\section{Metodologi Penelitian}

\section{A. Desain Penelitian/Research Design}

Pada tahap penyusunan research design disusun melalui pemahaman studi pustaka, kompilasi data awal dan penyusunan Rencana Kerja serta instrumen penelitian. Pada tahap ini yang dilakukan sebagai berikut :

1) Merumuskan dalam metodologi untuk memudahkan langkah-langkah apa saja yang harus disiapkan dalam pelaksanaan penelitian

2) Selanjutnya merancang desain penelitian

3) Setelah merumuskan metodologi dan merancang desain penelitian, maka dilakukan kompilasi data dan studi awal berupa penelaahan data-data terkait Performansi Industri Kelapa.

Disamping melakukan penelaahan data dan informasi awal, peneliti juga melakukan studi berupa kajian-kajian terhadap literatur ataupun studi-studi yang telah dilakukan, peraturan formal terkait, kebijakan pemerintah guna menghimpuan informasi awal tentang Performansi Industri Kelapa.
Pada gambar 2. adalah Research design secara garis besar.

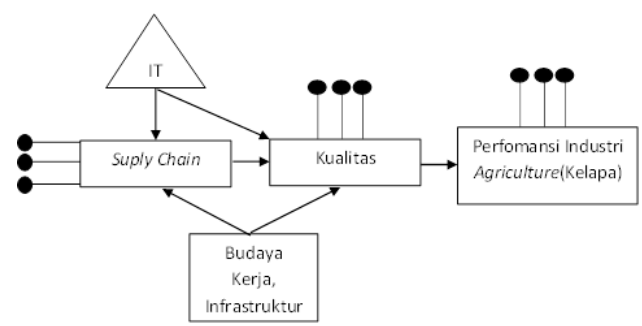

Gambar 2. Flow chart research design

\section{B. Metoda Pengumpulan Data/ Pelaksanaan Survei}

Data yang digunakan dalam penelitan ini adalah data primer dan sekunder. Data primer didapat melalui pengamatan langsung di lapangan serta wawancara secara langsung. Wawancara akan dilakukan dengan pihak perusahaan, terkait logistik perusahaan untuk mengetahui gambaran rantai pasok serta pengelolaan rantai pasok yang dilakukan oleh perusahaan. Selain itu, akan dilakukan wawancara dengan petani kelapa serta pengumpul untuk mengetahui kondisi harga kelapa terkini serta alur bahan baku kelapa dari petani ke supplier.

Data sekunder diperoleh dari literatur yang relevan, serta dokumen dan laporan yang dimiliki oleh perusahaan dan instansi terkait.

\section{1) Survey Sekunder}

Survey sekunder diaplikasikan dengan melakukan kegiatan kunjungan ke lokasi penelitian. Tujuan dari kegiatan ini adalah untuk mengumpulkan data-data pendukung sebagai bahan analisis urgensi. Adapun target dari kegiatan ini adalah:

- Terkumpulnya data dan informasi rantai pasok industri kelapa.

- Teridentifikasinya gambaran kondisi awal Performansi Industri Kelapa.

- Untuk mencapai target-target tersebut, maka survey difokuskan pada agendaagenda pendukung Performansi Industri Kelapa sebagai berikut :

- Pengumpulan data visual, statistik, data laporan, dll.

- Wawancara dengan instansi terkait yang dikunjungi untuk memperkaya informasi.

2) Survey Primer

Survey primer dilakukan untuk mengumpulkan persepsi dari responden terhadap suatu obyek penelitian. Kegiatan survey dilakukan dengan wawancara mendalam, kuisioner (angket) dan observasi lapangan mengenai rantai pasok yang menyangkut Performansi Industri Kelapa. 
a). Wawancara Mendalam

Wawancara mendalam (Indepth Interview) dilakukan terhadap stakeholders yang memiliki kompetensi di bidang rantai pasok dan keindustrian. Tujuan wawancara mendalam (indepth interview) adalah untuk menggali lebih mendalam informasi tentang konsep, permasalahan, kendala, strategi, dan realitas dalam program dan kebijakan Performansi Industri Kelapa. Selain itu Indept Interview dilakukan untuk memperdalam dan memperluas wawasan studi serta mempertajam analisis yang digunakan dalam kegiatan ini.

b). Observasi

Observasi adalah kegiatan pengamatan yang dilakukan langsung terhadap objek observasi tanpa melibatkan pihak lain. Kegiatan observasi dilakukan dengan menggunakan kerangka dan mekanisme tertentu

\section{Konsepsi Pengukuran Variabel}

Penelitian ini berfokus pada pengelolaan aliran material serta aliran informasi dari rantai pasok industri kelapa. Adapun variabel yang akan digunakan adalah sebagai berikut:

1. Tahap pengelolaan permintaan

Permintaan pelanggan menjadi acuan perusahaan untuk semua kegiatan pada perusahaan. Tahap ini juga terkait dengan sistem order yang diterapkan oleh perusahaan.

2. Tahap persediaan bahan baku

3. Tahap produksi

4. Tahap Distribusi

\section{Metoda Analisis Data}

Hasil dari observasi dan wawancara dianalisis dengan metode analisis kualitatif deskriptif. Tahap-tahap dalam analisis kualitatif, yaitu (1) reduksi data, (2) penyajian data, (3) penarikan kesimpulan [17]. Analisis deskriptif digunakan untuk memberikan gambaran atau uraian atas suatu keadaan sejelas mungkin tanpa ada perlakuan terhadap obyek yang diteliti [18]. Gambaran model rantai pasok industri kelapa, mulai dari supplier bahan baku hingga konsumen serta pengelolaan aliran material dan aliran informasi dideskripsikan secara terperinci.

\section{HASIL PENELITIAN}

Bagi masyarakat Sula, kelapa merupakan komoditas strategis karena selain sebagai sumber pendapatan juga memiliki peranan sosial dan kultural. Akan tetapi saat ini, keadaan perkelapaan di kabupaten Kepulauan Sula kurang menguntungkan terutama bila ditinjau dari produktivitas tanaman dan harga jual. Harga jual butiran kelapa masih rendah berkisar antara Rp 700 - 1000 per butir. Produktivitas tanaman kelapa per hektar di kabupaten Kepulauan Sula tidak pernah melampaui 1,2 ton ekuivalen kopra/ha/th. Hal ini jauh di bawah produktivitas tanaman kelapa yang dipelihara secara intensif yang dapat mencapai jumlah 2,5 - 3 ton ekuivalen kopra/ha/th. Olahan kelapa yang selama ini dikenal dan populer di masyarakat adalah minyak kelapa cara tradisional atau minyak kelentik. Minyak ini sering digunakan sebagai penyubur dan penghitam rambut, serta pelancar proses kelahiran. Akan tetapi minyak kelentik tidak tahan simpan

\section{A. Inbound Logistik}

Proses kesiapan bahan baku kelapa di wilayah kepulauan sula didukung sumber daya alam potensial kelapa saat ini yang mencapai 86.472 ton dalam satu tahun, dengan luas lahan mencapai 61.658 Ha dengan potensi tersebut bahwa secara suplai bahan baku akan mendukung kegiatan pengolahan kelapa menjadi minyak kelapa, Kegiatan pemanenan kopra di kepulauan sula mencapai 3 kali per tahun oleh 18.210 KK petani, maka komoditas ungulan ini mempunyai potensi secara bahan baku.

\section{B. Olahan Kopra}

Dilihat dari kondisi geografisnya, hampir sebagian besar luas lahan di Kepulauan Sula merupakan Perkebunan dan Kehutanan. Berdasarkan informasi Dinas Perkebunan Kabupaten Kepulauan Sula Tahun 2013, luas areal yang di gunakan untuk perkebunan kelapa yaitu sebesar 61.658 Ha. Kelapa sebagai salah satu produk perkebunan masyarakat di Kepulauan Sula yang menjadi mata pencaharian pokok yang dilakukan oleh masyarakat. Hasil dari perkebunan kelapa ini diolah menjadi Kopra dan kemudian baru dapat dipasarkan kepada pengepul ataupun langsung di jual ke daerah lain, seperti Surabaya dan Manado.

Untuk jenis produksi Kopra, jumlah produksi pada tahun 2012 adalah 86.492 ton, dengan tingkat produkstivitas $1.582 \mathrm{Kg} / \mathrm{Ha}$. Untuk jumlah petani Kopra di Kabupaten Kepulauan Sula dihitung berdasarkan Kepala Keluarga ada sekitar 18.210 KK. Jenis perkebunan Kopra ini dipanen 3 kali per tahun, dengan harga jual ke pasar sebesar Rp. 2500 $/ \mathrm{Kg}$ dan biasanya dikumpulkan terlebih dahulu kemudian diolah menjadi Kopra baru dapat di pasarkan. Jenis transportasi yang digunakan untuk penjualan keluar daerah melalui kapal laut dengan kapasitas muat kapal antara 30 - 50 ton tepatnya berada di pelabuhan Sanana.

Di bawah ini, gambar 1 adalah gambar rantai pasokan Kelapa di kabupaten Kepulauan Sula. 


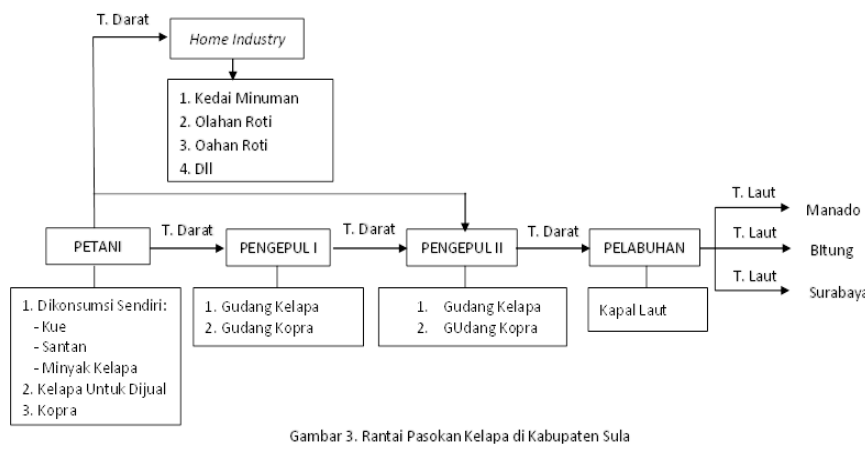

Dari gambar 1 dapat dilihat orang atau lembaga yang terlibat dalam rantai pasokan Kelapa yang dimulai dari Petani, home industry, Pengepul ke-1, Pengepul ke-2, dan pihak pelabuhan sebelum kopra dikirim dengan kapal laut ke daerah Manado, Bitung, dan Surabaya.

Pihak Petani ketika memanen Kelapa bisa menggunakannya dengan lima manfaat/ kegiatan. Yaitu :

1. Dikonsumsi sendiri, misalnya dibuat minyak kelapa untuk kebutuhan sendiri, untuk campuran kue, masakan, dll.

2. Dibuat Kopra terlebih dahulu, untuk dijual ke Pengepul

3. Langsung dijual ke Pengepul I

4. Langsung dijual ke Pengepul II

5. Dijual ke pihak industri rumahan seperti kedai makanan/ minuman, olahan kue/ roti, dll.

Pengangkutan dilakukan dengan moda transportasi darat (mobil pick up).

Pihak Pengepul I, melakukan kegiatan :

1. Menerima Kopra dari Petani, dan disimpan di Gudang Kopra

2. Menerima buah Kelapa, disimpan di Gudang Kelapa sebelum dibuat Kopra.

Pengangkutan dilakukan dengan moda Transportasi darat (mobil pick up).

Pihak Pengepul II, melakukan Kegiatan :

1. Menerima Kopra dari Pengepul I, dan disimpan di Gudang Kopra

2. Menerima Kopra dari Petani, dan disimpan di Gudang Kopra.

3. Menerima buah Kelapa dari Petani, dan disimpan di Gudang Kelapa sebelum dibuat Kopra.

4. Membawa hasil Kopra nya ke Pelabuhan untuk dimuat ke Kapal Laut, sesuai tujuan kota pengiriman, yaitu Manado, Bitung, atau Surabaya.

Pengangkutan dilakukan dengan moda transportasi darat, kecuali ketika pengangkutan untuk pengiriman ke tiga kota tujuan Manado, Bitung, dan Surabaya dilakukan pengiriman dengan Kapal Laut.

\section{IV.PEMBAHASAN}

A.

\section{Analisis Rantai Pasok}

Dari aliran rantai pasok yang terlihat pada gambar 1 bisa dilihat rantai pasokan yang tidak efektif dan efesien, baik dari segi waktu maupun biaya. Dengan hanya mengolah buah kelapa menjadi Kopra saja, nilai ekonomi yang didapat hanya sedikit. Sehingga perlu adanya produk kelapa yang lebih bernilai ekonomi. Salah satu yang direkomendasikan adalah produk olahan kelapa menjadi Minyak Kelapa.

Industri pengolahan daging buah kelapa yang menjadi pilihan yaitu industri minyak kelapa. Perkembangan penawaran dan permintaan minyak kelapa cukup baik. Pasar yang berkembang untuk produk tersebut telah menciptakan peluang ekspor bagi negara-negara penghasil kelapa. Anggota rantai pasokan untuk unit pengolahan daging buah kelapa ini yaitu terdiri dari: petani pemasok kelapa butiran, pedagang pengumpul dan atau pedagang perantara, agroindustri pengolah dan distribusi ke konsumen. Pemasok bahan baku bukan hanya dari petani pemasok kelapa butiran namun juga dari pedagang pengumpul dan atau pedagang perantara untuk unit pengolah daging buah kelapa.Petani penghasil kelapa butiran selaku pemasok bahan baku utama berupa kelapa butiran dapat melakukan pemasokan langsung ke unit pengolahan daging buah kelapa berupa unit pengolahan minyak kelapa. Kelapa butiran yang dihasilkan dari petani dapat langsung didistribusikan ke unit pengolahan untuk memenuhi kapasitas unit pengolah. Petani atau kelompok tani berfungsi sebagai pemasok utama, kekurangan bahan untuk kapasitas olah dipenuhi dari pedagang pengumpul dan atau pedagang perantara dari luar wilayah sentra tersebut.

Agroindustri pengolah merupakan unit yang mentransformasikan bahan baku menjadi produkproduk yang diinginkan. Agroindustri kelapa terpadu yang dikembangkan ini dengan unit pengolah buah kelapa yang menghasilkan minyak kelapa. Buah kelapa butiran yang dipasok dari petani akan langsung diolah ataupun disimpan terlebih dahulu dalam gudang penyimpanan bahan baku sebelum dilakukan proses transformasi. Produk minyak kelapa yang dihasilkan selanjutnya disimpan terlebih dahulu dalam gudang penyimpanan produk sebelum didistribusikan ke konsumen. Hasil samping pemrosesan berupa air kelapa, sabut kelapa dan tempurung kelapa, masing-masing akan ditampung dalam gudang penyimpanan untuk selanjutnya didistribusikan ke unit pengolahan yang lain. Agroindustri 
pengolahan kelapa terpadu ini dengan konsep mendistribusikan langsung produk agroindustrinya.

\section{B. Analisis Distribusi Olahan Produk Kelapa (Minyak Kelapa)}

Jalur distribusi minyak kelapa dari sentra produksi kelapa yaitu meliputi minyak kelapa dari unit pengolahan daging buah kelapa/ pengusaha didistribusikan ke pedagang di pasar tradisional dan pedagang eceran dan selanjutnya dijual ke konsumen. Konsumen ini merupakan konsumen pengguna langsung atau konsumen rumah tangga dan konsumen industri. Oleh sebab itu model rantai pasokan untuk agroindustri kelapa terpadu ini diharapkan dapat memberikan gambaran nilai tambah kepada petani selaku pemasok bahan baku dan petani atau kelompok tani yang memungkinkan untuk memiliki keterlibatan langsung dalam usaha ini meskipun bukan dari sisi manajerial pengelolaan unit pengolahan.

\section{KESIMPULAN}

Yang berperan dalam rantai pasokan kelapa di kabupaten Kepulauan Sula adalah Petani, Pengepul I, Pengepul II, Pemilik industri rumahan, Pemilik kendaraan angkut dan kapal laut sebagai moda transportasi. Dengan jalur Rantai Pasokan seperti ini hanaya sedikit keuntungan yang didapat oleh petani maupun pelaku usaha. Nilai Tambah dari Kelapa dan Kopra sangat kecil, berarti Nilai ekonomi yang didapatpun sangat kecil.

Untuk memberikan nilai tambah/ nilai ekonomi lebih besar bagi penduduk kabupaten Kepulauan Sula terutama bagi petani Kelapa dan pelaku usaha Kelapa, makan buah Kelapa harus diolah tidak hanya sampai Kopra tetapi dibuat minyak Kelapa berskala industri.

\section{REFERENSI}

[1] Pusat Komunikasi Publik Kementrian Perindustrian, 2015, Rencana Induk Pembangunan Industri Nasional, Kementrian Perindustrian, Jakarta

[2] Indrajit, R.E., Djokopranoto, R. (2003). Konsep Manajemen Supply Chain : Cara Baru Memandang Mata Rantai Penyediaan Barang. Grasindo. Jakarta

[3] Budiman, C., Massie, J., \& Wullur, M. 2015. Identifikasi desain jaringan manajemen rantai pasok kopra di Kota Manado (Studi di Kelurahan Bengkol dan Kelurahan Tongkaina). Jurnal Riset Ekonomi, Manajemen, Bisnis dan Akuntansi 3(2):65-76

[4] Wibowo, A. 2014. Analisis Kinerja Manajemen Rantai Pasokan Pada KUD Susu Sumber Makmur Ngantang. Skripsi Universitas Muhammadiyah Malang.

[5] United Nation Commodity Trade [UN comtrade]. 2016. Commodity Statistic. http://comtrade.un.org/db. (diakses 2 Juni 2019)
[6] Abdurachman, A., \& Mulyani, A. 2003. Pemanfaatan lahan berpotensi untuk pengembangan produksi kelapa. Jurnal Litbang Pertanian 22(1):

[7] Schroeder, Roger G. (2007). Manajemen Operasional. Erlangga. Jakarta.

[8] Heizer J., and Render, B. (2006) Operations Management. Pearson Education, Inc., Upper Saddle River. New Jersey. USA.

[9] Bowersox, Donald J. (2002). Manajemen Logistik : Integrasi Sistem-Sistem ManajemenDistribusi Fisik dan Manajemen Material : Edisi Ketiga. Jakarta : P.T. Bumi Aksara.

[10] Piri, S.D., Jorie, R.J. (2016). Analisa Rantai Pasokan Produk Turunan Kelapa (Studi Pada P.T. Royal Coconut Minahasa Utara). Jurnal EMBA, 4(2), 622-631.

[11] Tompodung, R.L., Lapian, J., Rate, P.V. (2016). Analisis Rantai Pasokan Pada Komoditas Kopra di Desa Elusan Kabupaten Minahasa Selatan. Jurnal EMBA, 4(4), 246255.

[12] Anis, C.S., Loho, A.E., Rumagit, G.A.J., (2017). Analisis Pengelolaan Rantai Pasok Tepung Kelapa Pada P.T. XYZ di Sulawesi Utara. Jurnal Agri-Sosioekonomi, 13(1), 81-90

[13] Jakfar, F., Romano, Nurcholis. (2015). Pengelolaan Rantai Pasok dan Daya Saing Kelapa Sawit di Aceh. Jurnal AGRARIS. 1(2), 108-113

[14] Hidayat, S., Marimin, Suryani, A., Sukardi, Yani, M. (2012). Model Identifikasi dan Strategi Peningkatan Nilai Tambah pada Rantai Pasok Kelapa Sawit. Jurnal Teknik Industri, 14(2), 89-96.

[15] Rosidi, A.R., Mustaniroh, S.A., Deoranto, P. (2017). Analisis Kelembagaan Rantai Pasok Agroindustri Kopra (Studi Kasus di Kabupaten Halmahera Utara). Jurnal Teknologi Pertanian, 18(2). 91-106

[16] A. Sutoni, "Determination of regional main products with fuzzy logic approach in regional Sula Island of North Maluku Province," in 3rd International Conference on Digital Arts, Media and Technology, ICDAMT 2018, 2018, doi: 10.1109/ICDAMT.2018.8376488.

[17] Sujarweni, V. W. (2014). Metologi Penelitian. Pustaka Baru Press. Yogyakarta.

[18] Kountur, R. (2009). Metode Penelitian : Untuk Peulisan Skripsi dan Tesis. PPM. Jakarta. 